\title{
Transmiterea materno-fetală a infecției cu HIV în Centrul Regional de Monitorizare şi Evaluare a infecției HIV/SIDA Craiova
}

\author{
Florentina Dumitrescu ${ }^{1,2}$, Eugenia-Andreea Marcu ${ }^{1,2}$, Mariana Stănescu ${ }^{1,2}$, \\ Lucian Giubelan ${ }^{1,2}$, Livia Dragonu ${ }^{1,2}$, Andreea Stoian ${ }^{1,2}$, Costin Berceanu ${ }^{1,3}$ \\ ${ }^{1}$ Universitatea de Medicină şi Farmacie, Craiova, România \\ ${ }^{2}$ Spitalul Clinic de Boli Infecţioase şi Pneumoftiziologie „Victor Babeş“, Craiova, România \\ ${ }^{3}$ Spitalul Clinic Judeţean de Urgenţă, Craiova, România
}

\begin{abstract}
REZUMAT
Infecţia cu HIV încă este asociată cu o mare morbiditate maternă, feto-neonatală şi infantilă. Depistarea precoce a infecţiei cu HIV în cursul sarcinii şi iniţierea rapidă a terapiei antiretrovirale sunt corelate cu obţinerea unei încărcături virale HIV mai mici de 50 copii/ml, în acest caz riscul de transmitere materno-fetală a infecţiei fiind mai mic de $0,5 \%$.

Obiective. Determinarea ratei transmiterii materno-fetale a infecţiei cu HIV în rândul gravidelor HIV pozitive aflate în evidenţa Centrului Regional de Monitorizare şi Evaluare a Infecţiei HIVISIDA din cadrul Spitalului de Boli Infecţioase şi Pneumoftiziologie „Victor Babeş” Craiova (CRC) şi identificarea unor corelaţii între aceasta şi anumiţi factori de risc.

Material şi metodă. Studiu retrospectiv, 01 ianuarie 2014-31 decembrie 2019, asupra a 73 de gravide HIV pozitive, aflate în evidenţa Centrului Regional Craiova (CRC). Pentru pacientele incluse în grupul de studiu am analizat: date demografice, date epidemiologice, date clinice, date biologice, date furnizate de examenul ginecologic şi obstetrical, date privind tratamentul antiretroviral (TARV). Copiii au fost evaluaţi biologic până la vârsta de 18 luni.

Rezultate. Am constatat o rată de transmitere materno-fetală de 6,3\%. Pentru pacientele la care s-au aplicat măsuri complete de profilaxie, rata transmiterii materno-fetale a fost de $3 \%$.

Aplicarea măsurilor complete de profilaxie s-a corelat cu risc scăzut de transmitere verticală a infecţiei cu HIV $(p=0,006)$. Aderenţa scăzută la TARV s-a corelat cu risc înalt de transmitere materno-fetală a infecţiei cu HIV $(p=0,02)$, cu încărcătură virală HIV (îV-HIV) detectabilă $(p=0,0004)$ şi cu imunodepresie avansată $(p=0,02)$. Stadiul bolii gravidelor HIV pozitive nu s-a corelat cu riscul de transmitere verticală a infecţiei $(p$ = 1). Nivelul ÎV-HIV a mamelor care au născut copii HIV pozitivi a fost mai mare decât la lotul general şi s-a corelat cu transmiterea materno-fetală $(p=0,04)$.

Concluzii. Rata transmiterii materno-fetale în perioada studiată a fost relativ crescută $(6,3 \%)$, din cauza aplicării incomplete a măsurilor de prevenţie, 12 dintre gravide fiind diagnosticate în timpul sarcinii sau la naşterea copilului. Transmiterea verticală a infecţiei cu HIV s-a corelat cu ÎV-HIV detectabilă şi aderenţă scăzută la TARV a gravidelor.
\end{abstract}

Cuvinte cheie: HIV, materno-fetal, transmitere

\section{INTRODUCERE}

La sfârşitul anului 2019, numărul persoanelor infectate cu virusul imunodeficienţei umane (HIV) la nivel global era de aproximativ 37,9 milioane, dintre care 19,6 milioane au fost femei. $82 \%$ dintre cele 1,3 milioane de femei însărcinate care trăiesc cu infecţie cu HIV la nivel mondial au primit tratament antiretroviral (TARV) pentru prevenirea transmiterii verticale a infecţiei (1).

În România, conform datelor Compartimentului pentru Monitorizarea şi Evaluarea Infecţiei HIV/ 
SIDA, la 31 decembrie 2019 se înregistrau 16.486 de persoane infectate HIV/SIDA în viaţă, dintre care 6.460 de femei. În anul 2019, s-au născut 185 de copii din mame HIV pozitive şi 184 au primit profilaxie ARV, 13 copii fiind HIV pozitivi (2).

Infecţia cu HIV încă este asociată cu o mare morbiditate maternă, feto-neonatală şi infantilă (3). Rata transmiterii perinatale a virusului imunodeficienţei umane în absenţa strategiilor de prevenire în perioada prenatală sau a travaliului şi a naşterii este cuprinsă între 15\% şi 45\% (1). Programele destinate prevenţiei transmiterii materno-fetale a infecţiei cu HIV fac parte din strategia de eliminare a cazurilor noi de infecţie cu HIV la copii (4).

În absenţa TARV, peste $80 \%$ dintre cazurile de transmitere au loc după 36 de săptămâni de amenoree, în timpul travaliului sau naşterii, şi doar $2 \%$ dintre transmiteri apar în primele două trimestre de sarcină (5). Transmiterea verticală poate fi prevenită prin screening prenatal, TARV pregestaţional şi atitudine obstetricală adaptată $(3,6)$.

Principalul factor predictiv al transmiterii materno-fetale este reprezentat de încărcătura virală HIV (ÎV-HIV) plasmatică maternă (7). Alţi factori de risc pregestaţionali sunt nivelul plasmatic matern scăzut al limfocitelor T CD4 şi boala avansată maternă (SIDA) (8). Factorii obstetricali cu rol în facilitarea transmiterii verticale a infecţiei cu HIV sunt: naşterea pe cale vaginală, naşterea prematură, procedurile obstetricale invazive din timpul sarcinii (amniocenteză, cordocenteză), corioamniotita, ruptura prematură de membrane (9).

Depistarea precoce a infecţiei cu HIV în cursul sarcinii şi iniţierea rapidă a terapiei antiretrovirale sunt corelate cu obţinerea unei încărcături virale HIV mai mici de 50 copii $/ \mathrm{ml}$, în acest caz riscul de transmitere materno-fetală a infecţiei fiind mai mic de $0,5 \%$. Reducerea riscului se poate realiza prin: supresia încărcăturii virale materne prin administrarea de antiretrovirale mamei până, cel puţin, în trimestrul al treilea de sarcină şi în special în timpul travaliului, reducerea expunerii fătului prin programarea unei operaţii de cezariană, profilaxia postexpunere a nounăscutului, alimentaţia artificială a nou-născutului (10).

Obiectivele acestui studiu sunt determinarea ratei transmiterii materno-fetale a infecţiei cu HIV în rândul gravidelor HIV pozitive aflate în evidenţa Centrului Regional de Monitorizare şi Evaluare a Infecţiei
HIV/SIDA din cadrul Spitalului de Boli Infecţioase şi Pneumoftiziologie „Victor Babeş“ din Craiova (CRC) şi identificarea unor corelaţii între aceasta şi anumiţi factori de risc.

\section{MATERIAL ŞI METODE}

Am efectuat un studiu retrospectiv, în perioada 01 ianuarie 2014-31 decembrie 2019, asupra a 73 de gravide HIV pozitive aflate în evidenţa CRC.

Pentru pacientele incluse în grupul de studiu, am analizat: date demografice, date epidemiologice, date clinice (examen clinic complet, prezenţa sau absenţa suferinţelor HIV asociate), date biologice (serologie pentru coinfecţii cu virusuri hepatitice, serologie pentru infecţii cu Toxoplasma gondii şi citomegalovirus, determinarea numărului de limfocite T $\mathrm{CD} 4+$ prin citometrie de flux- flowcitometrul FACS-COUNT, determinarea ÎV-HIV prin metoda polimerizării în lanţ - PCR), date furnizate de examenul ginecologic şi obstetrical, date privind tratamentul antiretroviral (durata administrării, tipul de schemă utilizat) şi date privind rezultatele chestionarului de aderenţă la TARV, interpretarea acestora de către psiholog şi măsurile întreprinse pentru îmbunătăţirea nivelului de aderenţă la TARV.

Nivelul aderenţei a fost apreciat conform criteriilor chestionarului de aderenţă (11):

- 20-22 puncte $=$ aderenţă $\geq 95 \%$

- $18-19$ puncte $=80 \%<$ aderenţă $<95 \%$

- $\quad$ sub 18 puncte $=$ nonaderenţă $(<80 \%)$

Am evaluat copiii la naştere, la 14-21 de zile, la 1-2 luni, la 2-3 luni, la 4-6 luni, la 12 luni prin determinarea ÎV-HIV (PCR-ARN HIV). După 18 luni, statusul HIV al copiilor a fost evaluat prin efectuarea testelor ELISA anticorpi anti-HIV 1,2 şi Western Blot HIV.

Datele au fost colectate utilizând baza de date electronice şi documentele medicale ale pacientelor aflate în evidenţa CRC. Pentru prelucrarea statistică a datelor am utilizat modulul Data Analysis al programului Microsoft Excel, iar pentru corelaţiile statistice pragul de semnificaţie a fost $p<0,05$. Rezultatele obţinute au fost sintetizate în tabele şi figuri.

\section{REZULTATE}

În rândul celor 73 de gravide HIV pozitive pe care le-am evaluat, au fost înregistrate 78 de naşteri în pe- 
rioada studiată - 3 dintre paciente au avut câte două naşteri şi o pacientă a avut 3 naşteri. O pacientă a prezentat sarcină gemelară obţinută prin fertilizare in vitro. S-au născut 79 de copii: 3 feţi morţi, 5 nou-născuţi confirmaţi cu infecţie cu HIV şi 71 de copii seroreverteri. Analizând statusul copiilor expuşi perinatal la infecţia cu HIV, am constatat o rată de transmitere materno-fetală de 6,3\%. Pentru pacientele la care s-au aplicat măsuri complete de profilaxie, rata transmiterii materno-fetale a fost de $3 \%$.

În ceea ce priveşte distribuţia anuală a numărului de gravide HIV pozitive, am constatat că numărul cel mai mare s-a înregistrat în anul 2018 (17 cazuri $21,8 \%$ ) şi cel mai mic în anul 2017 (8 cazuri - 10,2\%).

Caracteristicile bazale ale lotului sunt prezentate în tabelul 1.

TABEL 1. Caracteristici bazale ale lotului

\begin{tabular}{|l|l|c|}
\hline \multicolumn{2}{|l|}{ Caracteristici bazale ale lotului } & $\begin{array}{c}\text { Număr paciente } \\
\text { nr (\%) }\end{array}$ \\
\hline Vârsta mamei la prima & $\leq 18$ & $2(2,7 \%)$ \\
& $19-24$ ani & $10(13,7 \%)$ \\
& $25-33$ ani & $60(82,2 \%)$ \\
& $\geq 34$ ani & $1(1,4 \%)$ \\
\hline Momentul & Anterior sarcinii & $61(83,6 \%)$ \\
diagnos ăgi infecției & & $7(9,6 \%)$ \\
cu HIV & sau travaliului & \\
& La naștere & $5(6,8 \%)$ \\
\hline Calea probabilă de & Parenteral & $52(71,2 \%)$ \\
infectare a gravidelor & Sexual & $21(28,8 \%)$ \\
\hline Mediul de proveniență & Urban & $17(23,3 \%)$ \\
& Rural & $56(76,7 \%)$ \\
\hline Școlarizare & $<8$ clase & $24(32,9 \%)$ \\
& $\geq 8$ clase & $49(67,1 \%)$ \\
\hline
\end{tabular}

Mediana vârstei gravidelor la momentul diagnosticării infecţiei cu HIV a fost de 16 ani [3:32], iar la prima naştere de 27 ani [14:34].

Referitor la statusul HIV al cuplurilor, au existat 25 de cazuri $(34,2 \%)$ cu ambii parteneri HIV pozitivi, 46 de cazuri (63\%) de tip serodiscordant şi 2 cazuri $(2,8 \%)$ cu status HIV necunoscut (partener netestat).

Dintre cele 73 de gravide aflate în studiu, 49 $(67,1 \%)$ se aflau în stadiul SIDA (clinic şi imunologic) la momentul primei naşteri (figura 1).

Evaluarea imuno-virusologică a gravidelor a evidenţiat o imunodepresie medie, cu o mediană a limfocitelor CD4 de 413 celule $/ \mathrm{mm}^{3}$ [19:1.272], 41\% dintre gravide având CD4 $>500$ celule $/ \mathrm{mm}^{3} ; 26 \%$ dintre gravide au avut ÎV-HIV nedetectabilă la naştere.

Gravidele din lotul studiat au prezentat şi coinfecţii/infecţii pe parcursul sarcinii, dintre care cea mai

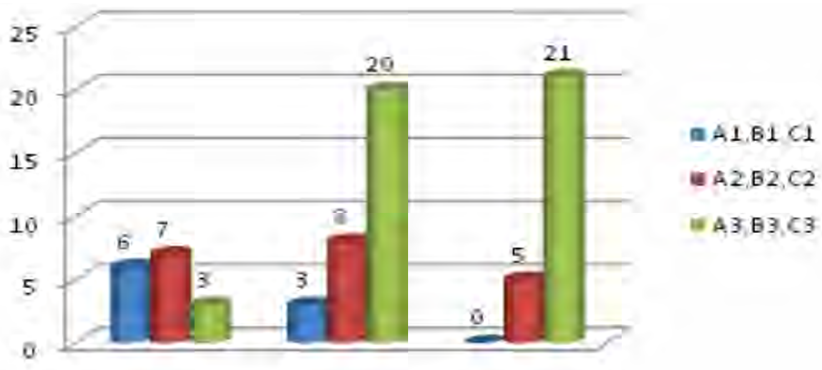

FIGURA 1. Clasificarea clinico-imunologică a gravidelor HIV pozitive

frecventă a fost hepatita cronică virală B - 10 cazuri $(13,7 \%)($ tabel 2).

TABEL 2. Coinfecții/infecții la gravidele din lotul studiat

\begin{tabular}{|l|c|}
\hline Hepatită cronică virală B & 10 cazuri $(13,7 \%)$ \\
\hline Hepatită cronică virală B+D & 1 caz $(1,4 \%)$ \\
\hline IgG anti-Toxoplasma gondii prezenți & 9 cazuri $(12,3 \%)$ \\
\hline IgG anti-citomegalovirus prezenți & 7 cazuri $(9,6 \%)$ \\
\hline Sifilis & 2 cazuri $(2,7 \%)$ \\
\hline Tuberculoză pulmonară & 2 cazuri $(2,7 \%)$ \\
\hline
\end{tabular}

Am constatat prezenţa comorbidităţilor precum hipertensiunea arterială (HTA) la 2 dintre paciente (HTA grad III şi HTA gestaţională) şi astmul bronşic la o pacientă.

Gravidele HIV pozitive au primit consiliere psihologică şi au fost efectuate evaluări periodice clinice şi biologice, în vederea urmăririi corecte şi informării pacientelor în legătură cu măsurile de profilaxie a transmiterii verticale a infecţiei cu HIV. Medicul infecţionist care a avut în îngrijire gravida HIV pozitivă a colaborat cu specialistul obstetrician, acesta din urmă programând cezariana pentru pacientele care s-au prezentat conform programărilor la evaluări.

Terapie antiretrovirală pentru profilaxia transmiterii materno-fetale a infecţiei cu HIV au primit 66 de paciente $(90,4 \%)$. Cea mai utilizată schemă ARV a fost Lamivudină/Zidovudină (3TC/ZDV) + Lopinavir/Ritonavir (LPV/r) - 31 de cazuri (47\%). 64 de paciente au primit tratament profilactic pe toată perioada sarcinii, iar 2 paciente au primit tratament doar în ultimul trimestru de sarcină. O pacientă a refuzat tratamentul antiretroviral pe perioada sarcinii (figura 2).

Mediana duratei tratamentului până la prima naştere a fost 11 ani [0:24].

Aderenţa gravidelor la TARV a fost evaluată prin aplicarea chestionarului de aderenţă, ce se completează periodic pentru toţi pacienţii infectaţi cu HIV aflaţi în evidenţa CRC. Am constatat că 18 paciente $(27,3 \%)$ au fost neaderente la TARV (aderenţă $<80 \%$ ) (figura 3 ). 


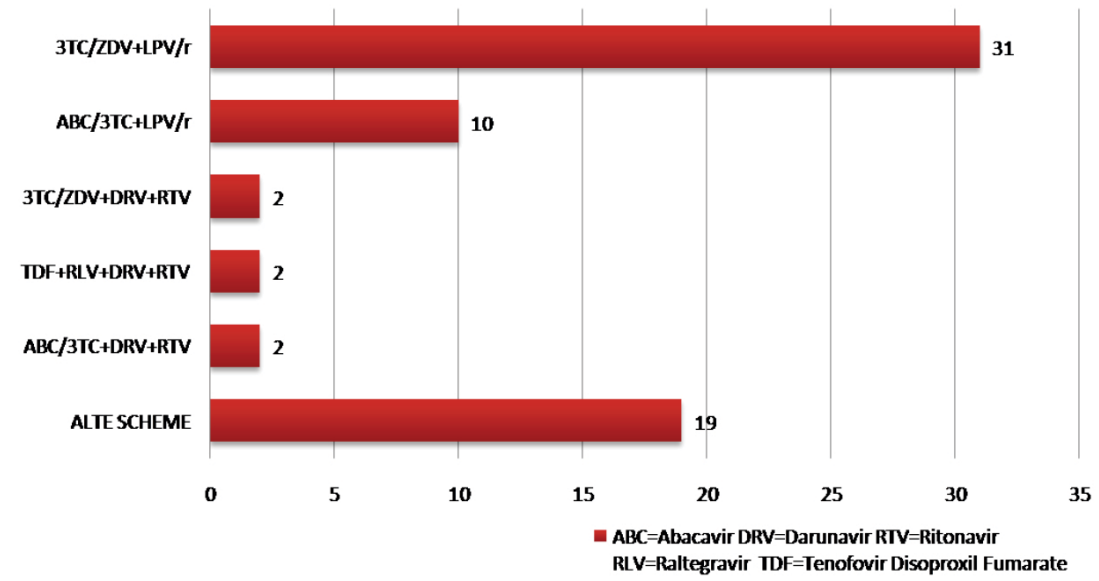

FIGURA 2. Regimuri antiretrovirale utilizate la gravidele HIV pozitive

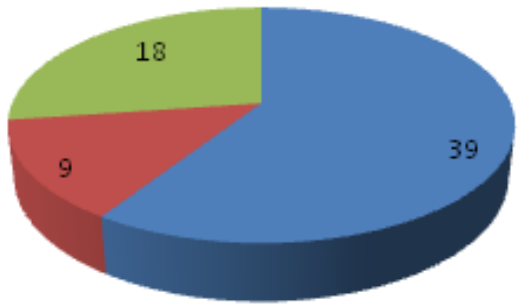

Aderentă $\geq 95 \%$ - $80 \%<$ Aderență $<95 \%$ Aderență $<80 \%$

FIGURA 3. Aderența la TARV a gravidelor HIV pozitive

Raportat la tipul naşterii, 11 femei $(14,1 \%)$ au născut pe cale naturală şi 67 de femei $(85,9 \%)$ prin operaţie cezariană. În cazul celor 6 paciente diagnosticate cu infecţie cu HIV anterior sarcinii, care au născut vaginal, acest fapt a fost urmarea, fie a prezentării pacientelor în travaliu, fie a fost alegerea pacientelor (au refuzat cezariana programată).

Aplicarea măsurilor complete de profilaxie (administrarea TARV la mamă, naşterea prin operaţie de cezariană, profilaxia ARV şi alimentaţia artificială a nou-născutului) s-a corelat cu risc scăzut de transmitere verticală a infecţiei cu HIV $(\mathrm{p}=0,006)$.

Aderenţa scăzută la TARV s-a corelat cu risc înalt de transmitere materno-fetală a infecţiei cu HIV ( $p=$ $0,02)$, cu viremia detectabilă $(p=0,0004)$ şi cu imunodepresia avansată $(\mathrm{p}=0,02)$.

Dintre cei 5 copii infectaţi vertical cu HIV, 2 au fost născuţi pe cale naturală şi 3 copii prin operaţie de cezariană. Nu au existat diferenţe statistice semnificative între naşterea vaginală şi naşterea prin cezariană referitor la rata transmiterii materno-fetale a infecţiei cu HIV (p = 0,1).
Toţi nou-născuţii au primit profilaxie ARV timp de 6 săptămâni, cea mai utilizată combinaţie fiind ZDV+3TC - 72 de copii (96\%) şi au fost alimentaţi artificial.

3 dintre copiii HIV pozitivi au provenit din mame infectate parenteral cu HIV în perioada 1987-1990, iar ceilalţi 2 provin din mame infectate cu HIV pe cale sexuală.

Stadializarea clinico-imunologică la naştere a celor 5 gravide HIV pozitive, ce au transmis vertical infecţia, a fost următoarea: o gravidă în stadiul C3, o gravidă în stadiul C2, o gravidă în stadiul B3, o gravidă în stadiul B2 şi o gravidă în stadiul A2 (diagnosticată în luna a VII-a de sarcină, cu TARV iniţiat imediat după depistare). Stadiul bolii gravidelor HIV pozitive nu s-a corelat cu riscul de transmitere verticală a infecţiei $(\mathrm{p}=1)$.

Evaluarea imunologică a mamelor ce au transmis vertical infecţia cu HIV, a evidenţiat un grad moderat de imunodepresie cu o mediană a limfocitelor CD4 de 319 celule $/ \mathrm{mm}^{3}$ [74:478]; nu au fost diferenţe statistice semnificative faţă de lotul cu copii negativi. Nivelul ÎV-HIV a mamelor care au născut copii pozitivi a fost mai mare decât la lotul general, două paciente având viremii mai mari de 10.000 copii/ml; nivelul ÎV-HIV s-a corelat cu transmiterea materno-fetală ( $\mathrm{p}$ $=0,04)$.

\section{DISCUṬII}

Sarcina în context HIV rămâne o situaţie de risc în toate cazurile; astfel, managementul gravidei HIV pozitive trebuie asigurat de o echipă multidisciplinară pentru o abordare completă şi corectă. 
$\mathrm{Au}$ fost elaborate recomandări şi îngrijiri specifice pentru gravida HIV pozitivă şi nou-născut, iar aplicarea riguroasă a acestor măsuri a condus la reducerea semnificativă a transmiterii verticale a infecţiei cu HIV la o rată mai mică de $1 \%(12,13)$.

Într-un studiu de cohortă amplu, efectuat în Ucraina în perioada 2000-1012, a fost analizat un lot de 8.884 paciente diagnosticate cu infecţie cu HIV anterior, în timpul sarcinii şi intraparturm, care au născut feţi vii. Diagnosticul infecţiei cu HIV a fost stabilit anterior sarcinii în 35\% dintre cazuri (2.951 paciente), comparativ cu $65 \%$ care au fost diagnosticate în timpul sarcinii astfel: 19\% (1.623 paciente) diagnosticate în primul trimestru, 27\% (2.291 paciente) în trimestrul al doilea, $15 \%$ (1.217 paciente) în trimestrul al treilea, respectiv $4 \%$ dintre cazuri (310 paciente) diagnosticate la naştere. TARV au primit $83 \%$ dintre mame în timpul sarcinii. În 30\% dintre cazuri, naşterea a avut loc prin operaţie de cezariană programată, în $4 \%$ dintre cazuri prin operaţie de cezariană efectuată în regim de urgenţă, iar în $66 \%$ dintre cazuri pe cale naturală. Acest studiu a demonstrat că rezultatele negative sunt condiţionate atât de factorii de risc asociaţi direct infecţiei cu HIV, cât şi de factorii de risc comuni populaţiei generale, evidenţiind importanţa monitorizării sarcinilor şi a tratamentului antiretroviral în rândul gravidelor HIV pozitive (14).

În studiul pe care 1-am efectuat, am identificat o rată de $6,3 \%$ a transmiterii materno-fetale a infecţiei cu HIV, comparativ cu o rată mai înaltă $(9,3 \%)$ raportată la CRC în perioada 2007-2011 (15).Transmiterea verticală a infecţiei cu HIV a fost asociată cu viremie HIV crescută şi aderenţă scăzută la TARV, similar cu date rezultate din mai multe studii (16-18).

Un alt studiu de cohortă a fost efectuat în Etiopia în perioada ianuarie 2014-decembrie 2017, asupra a 313 gravide HIV pozitive. Rata de transmitere materno-fetală a infecţiei cu HIV a fost de 3,8\%. Absenţa controalelor periodice în timpul sarcinii (56 paciente $-19,9 \%$ ), naşterea la domiciliu (51 paciente $-16,3 \%$ ), absenţa TARV la gravide (23 paciente $-7,3 \%$ ) şi absenţa TARV profilactic al nou-născuţilor (21 nou-născuţi nu au primit tratament ARV - 6,7\%) au fost factori de risc semnificativ asociaţi cu transmiterea verticală a infecţiei cu HIV (19).

Administrarea corectă a TARV la gravida HIV pozitivă, în vederea obţinerii şi menţinerii supresiei virale, rămâne obiectivul principal al îngrijirii, acesta fiind unul dintre factorii cei mai importanţi care influenţează transmiterea verticală a infecţiei cu HIV. Diagnosticarea infecţiei cu HIV a gravidelor la momentul naşterii aduce în atenţie deficienţe în îngrijirea şi monitorizarea gravidelor; este necesară informarea tuturor femeilor care doresc să aibă un copil în legătură cu necesitatea testării HIV, pentru a putea lua o decizie în cunoştinţă de cauză, în funcţie de statusul HIV.

\section{CONCLUZII}

Rata transmiterii materno-fetale în perioada studiată a fost relativ crescută $(6,3 \%)$, din cauza aplicării incomplete a măsurilor de prevenţie.

S-au evidenţiat deficienţe în îngrijirea şi monitorizarea gravidelor, 12 dintre gravide fiind diagnosticate în timpul sarcinii sau la naşterea copilului.

Transmiterea verticală a infecţiei cu HIV s-a corelat cu viremie HIV detectabilă şi aderenţă scăzută la TARV a gravidelor.

Instituirea corectă a măsurilor complete de profilaxie (TARV la mamă, aderenţa la tratament, operaţia cezariană, profilaxia ARV şi alimentaţia artificială a nou-născutului) s-a însoţit de un risc scăzut al transmiterii materno-fetale a HIV, fiind necesară intervenţia unei echipe multidisciplinare pentru monitorizarea gravidei HIV pozitive şi a copilului expus perinatal la infecţia cu HIV.

\section{BIBLIOGRAFIE}

1. https://www.who.int/news-room/fact-sheets/detail/hiv-aids. [Online] November 15, 2019 [Cited April 30, 2020].

2. http://cnlas.ro/com_jce/date-statistice.html [Online] [Cited May 05, 2020].

3. Royal College of Obstetricians and Gynaecologists. HIV in Pregnancy, Management (Green-top Guideline No. 39). Published 2010.

4. Gubert De Matos VT, Lyrio De Oliveira AL, Ribeiro Dos Santos E et al. Missed opportunities for prevention of perinatal HIV infection. Braz J Infect Dis. 2015;19(5):554-555.

5. Kourtis AP, Bulterys M, Nesheim SR, Lee FK. Understanding the timing of HIV transmission from mother to infant. The Journal of the American Medical Association. 2001;(285):709-12.

6. http://www.guideline.gov/summary/summary.aspx?doc_id=7676\&nbr $=004475 \&$ string $=$ Management+AND+ HIV+AND+pregnancy. [Online] 2004. [Cited April 24, 2020.]

7. Garcia PM, Kalish LA, Minkoff H, Quinn TC, Burchett SK et al. Maternal levels of plasma human immunodeficiency virus type 1 RNA and the risk of perinatal transmission. N Engl J Med. 1999; 341:394-402. 
8. European Collaborative Study. Maternal viral load and vertical transmission of HIV-1: An important factor but not the only one. AIDS. 1999;13:1377-85.

9. European Collaborative Study. Risk factors for mother-to-child transmission of HIV-1. Lancet. 1992;339(8800):1007-1012.

10. European AIDS Clinical Society (EACS) Guidelines for treatment of HIV-positive adults in Europe. October 2018 - available at https:// www.eacsociety.org/files/2018_guidelines-9.1-english.pdf.

11. Drăgănescu $M$, lancu $A V$, Modrigan $M$, Arbune $M$. Aderența la tratamentul antiretroviral și trăsăturile de personalitate ale pacienților cu infectie HIV. Probleme de patologie infectioasă la frontiere. Conferința Națională cu participare internaţională „Patologia infecțioasă la frontiere" Galați, 7-9 iunie 2018, Editura GUP, 2018.

12. https://www.cdc.gov/hiv/group/gender/pregnantwomen/index.html [Online] 2019. [Cited May 12, 2020].

13. Townsend CL, Cortina-Borja M, Peckham CS et al. Low rates of mother-to-child transmission of HIV following effective pregnancy interventions in the United Kingdom and Ireland, 2000-2006. AIDS. 2008;22(8):973-81.
14. Bakeris E, Malyuta R, Volokha A et al. Pregnancy Outcomes in HIV-positive Women in Ukraine, 2000-12 (European Collaborative Study in EuroCoord): An Observational Cohort Study. Lancet HIV. 2015;2(9:e385-92.

15. Dumitrescu F, Cupșa A, Giubelan L et al. Expunerea perinatală la infecția cu HIV în perioada 2007-2011 în județul Dolj. Ro J Infect Dis. 2012;15(3):194-195

16. Warszawski J, Tubiana R, Le Chenadec J et al. Mother-to-childtransmission despite antiretroviral therapy in the ANRS French Perinatal Cohort. AIDS. 2008;22:289-99.

17. Teasdale CA, Marais BJ, Abrams EJ. HIV: Prevention of mother-tochild transmission. BMJ Clin Evid. 2011.

18. Hurst SA, Appelgren KE, Kourtis AP. Prevention of mother-to-child transmission of HIV Type 1: the role of neonatal and infant prophylaxis. Expert Rev Anti Infect Ther. 2015:169-181.

19. Yitayew YA, Bekele DM, Demissie BW, Menji ZA. Mother to Child Transmission of HIV and Associated Factors Among HIV Exposed Infants at Public Health Facilities, Dessie Town, Ethiopia. HIVIAIDS - Research and Palliative Care. 2019;11. 